\title{
Trans Power! Sylvia Lee Rivera's STAR and the Black Panther Party
}

\author{
Samuel Galen Ng, New York University
}

"We were all fighting the same thing: Oppression."

- Sylvia Lee Rivera (1990) ${ }^{1}$

In August of 1970, Huey P. Newton issued a manifesto in the Black Panther Party (BPP) newspaper encouraging an alliance between the Panthers and Women's as well as Gay Liberation. While the declaration simultaneously alluded to homophobic and sexist attitudes, it was the first public statement of support for Gay Liberation by a "straight" black organization. ${ }^{2}$ Newton, the Panthers' Minister of Defense, went so far as to embrace a fluid conception of sexuality, implying that homophobia stemmed from a Freudian fear of one's own homosexuality. As such, he called for the embrace of gay people as familiar or even familial comrades, characterizing them as possibly the "most oppressed" and "most revolutionary" minority group in the United States. ${ }^{3}$

Revisionist scholarship on the BPP has praised Newton's coalitionbuilding efforts for lending critical "mainstream" support to what was still a fledgling, post-Stonewall, gay civil rights movement. Yet this welcome work has all-too-often presented this alliance as one between straight black and gay white people. ${ }^{4}$ While this dichotomy does have historical grounding - Newton saw the alliance less in terms of directly overlapping interests and more as a practical means to gain support from other groups generally mired in capitalist, police oppression - it elides the efforts of queer people of color who worked in and alongside the BPP to serve their own communities.

Addressing this scholarly lacuna can shed particular light on how the Panthers opened doors not only for Gay Liberation but also a nascent and yetto-be-named transgender movement, seen through the figure of Sylvia Lee Rivera (1951-2002), a Puerto Rican-Venezuelan transvestite, born Ray Rivera Mendoza, who helped incite the Stonewall Rebellion and founded STAR (Street Transvestite Action Revolutionaries), a radical, pioneering yet short-lived trans rights organization, which included a "house" in the Lower East Side that sheltered homeless trans women and queer of color youth. ${ }^{5}$ While a few scholars have indicated Rivera's connection to the BPP, their mentions are brief and relegated to the fields of queer studies. ${ }^{6}$ Even Layli Phillips's and Shomari Olugbala's article, "Sylvia Rivera: Fighting in Her Heels," one of the few to locate Rivera within the broader civil rights movement, focuses specifically on her efforts at Stonewall. Although the article notes Rivera's associations with the BPP, it tellingly misidentifies the city in which Rivera met Newton as 
Philadelphia instead of Washington DC, indicative of a larger lack of scholarly interest in, and attention to the details of, this connection. ${ }^{7}$

Rivera maintained close, if largely indirect, ties with the Panthers. She marched alongside the Young Lords, a Puerto Rican nationalist group centered in East Harlem that worked intimately with the Panthers, and came to admire Newton, following his declaration of allegiance. While scholars like Phillips and Olugbala have pointed to the Panthers' rampant homophobia at this time, Rivera described her five-minute chat with Newton at the 1970 Revolutionary People's Constitutional Convention in Washington DC as one of her "greatest experiences." Newton recognized Rivera at the Convention and referred to her affectionately as "that queen from New York." ${ }^{8}$ While Rivera has been appreciated as a trans activist, her relationship with the Panthers has not been fully explored. Examining this relationship will manifest the way trans (of color) organizing has developed particularly through the revolutionary iterations of Black Power and within community infrastructures like the STAR house, which instantiated for Rivera the "apex" of her political career.?

Still, Rivera's direct relationship with the Panthers was quite limited, which perhaps explains its lack of recognition. Besides her one-time meeting with Newton and the financial support she gave to the BPP via her affiliation with the Gay Liberation Front, there remain few instances of actual correspondence. ${ }^{10}$ Rivera's open veneration for the BPP, however, suggests that scholars ought to read more into moments of engagement between her and the Panthers that might otherwise seem circumstantial. Indeed, few activists in the late 1960s and early 1970s could call for "Revolution" and "Power" without alluding to the Panthers in some way. According to sociologist George Katsiaficas, the BPP was the most "influential revolutionary organization" in the United States in these years. J. Edgar Hoover and the Federal Bureau of Investigation (FBI) saw the Panthers as the "greatest threat" to internal security. Government efforts to arrest, assault, and murder Panther leaders galvanized college students, minorities, and counterculturists to act in coalition with them against what they came to see as an oppressive capitalist state that disfranchised all people. ${ }^{11}$

The revolutions of " 1968 " involved a concerted, global effort by students, workers, racial and sexual minorities to ally with each other and articulate new conceptions of power. They saw revolutionary potential in their rejection of all forms of authoritarianism, including Old Leftist notions of class-based alliance and struggle. In their very act of locating power among a specific cadre governing the state and its various disciplinary institutions, namely the police, the legal and carceral system, and the hospitals, they simultaneously enacted a new kind of polyglot power of the "people," an inclusive constituency of the "oppressed" that such declarations sought to bring into being. ${ }^{12}$ 
In the words of contemporary political theorists Ernesto Laclau and Chantal Mouffe, the New Left revolutionaries endeavored to establish "chains of equivalence" across a variety of disparate movements, such as black civil rights, the antiwar movement, second wave feminism, the American Indian Movement, and gay liberation. For Laclau and Mouffe, "society" is a discursive formation that is continually in a process of becoming. Practices, beliefs, and assumptions interact with each other to form various "hegemonies," which exist through pluralistic and precarious relations. The unexpected constitution and assertion of new discourses, like "Gay Power," can create an "antagonism" within hegemonic society that results in the destabilizing of identities and the reshaping of previously existing discourses like "Black Power." The assertions of such antagonistic discourses are required to interrupt and make manifest processes of subordination, but they can do so only when they become available — the articulation of "Gay Power" requires that a "Black Power" enter the public sphere first. Laclau and Mouffe thus see revolutionary potential in disruptive, hegemonic articulations. While these articulations require tremendous effort, they have the capacity to confront neoliberal discourses by creating "chains of equivalence" and possibly new hegemonic blocs of the oppressed and the concomitant establishment of new discourses like "Power to the People." 13

The utopian end result for Laclau and Mouffe would be the institution of a "radical democratic politics," a pluralist democracy where various groups would be linked together in common struggle via hegemonic articulation without losing their autonomy. Indeed, Rivera's life achievement was to constitute a new, autonomous discourse of trans-identification precisely through her efforts and those of the BPP to articulate "chains of equivalence," a dwelling together in and against oppression. Unfortunately, as Laclau and Mouffe also suggest and which Rivera would eventually come to see, such "equivalences" are never fully equivalent; they remain as fragile as the discourses they reshape and thus require maintenance and a prioritizing of autonomies for stability. ${ }^{14}$

\section{Beyond Black Nationalism: The Panthers' Precarious Alliance}

Huey Newton and Bobby Seale drew upon Frantz Fanon's theorization of the revolutionary potential of the colonized "lumpenproletariat" — the rogues, prostitutes, thieves, hustlers, murderers, gamblers, and paupers — in their founding of the Black Panther Party for Self-Defense in 1966. They sought to empower and organize their dispossessed brothers and sisters off the street, who could otherwise, according to Fanon, become allied with an oppressive imperialcapitalist system. Neither exactly "revolutionary" nor "reformist," the community-based free breakfast programs, health clinics, and liberation youth schools that the Panthers implemented were meant to be "survival programs." 15 Newton saw 
as a precursor to revolution the establishment of such survival-oriented community infrastructures; they were to sustain the basic wellbeing of black "street" people - an ideology that Rivera would adopt in her own efforts to house and feed "street transvestites" and other potentially revolutionary agents of the lumpenproletariat. ${ }^{16}$

The Panthers' first move away from a quasi-nationalist to a more "hegemonic" socialist position occurred through its official alliance with a white, California-based political group, the Peace and Freedom Party (PFP) in December of 1967. The PFP had sought to support Huey Newton, who had been in prison until October of that year for assault with a deadly weapon and later for voluntary manslaughter, but soon expanded its agenda to address larger issues pertaining to black liberation within the class struggle. By allying with the PFP, the BPP gained financial aid and administrative resources to generate and popularize its so-called "Free Huey Movement." The BPP, which had originally embraced a more exclusivist black nationalist ideology, soon came to work alongside other "white" organizations engaged in a revolutionary socialist project, including Students for a Democratic Society (SDS), which declared its support for the Panthers in March of 1969, and the Gay Liberation Front (GLF), which came to regard the Panthers as the "vanguard" of the revolution by September of $1970 .{ }^{17}$

The BPP's dramatic visibility in the public sphere, which broadcast its declarations of pride and community, provided groups like GLF a "metonymic leverage," in Kobena Mercer's words, to assert claims to "gay pride" or "global sisterhood."18 Gay and women's liberation both appealed to the Panthers' original Ten-Point Program of 1966 to expand their demands for "reform" and "equality" into wider aspirations of revolution. ${ }^{19}$ The BPP thus became a media and mediator of sorts for the absorption and appropriation of the liberationist sentiments of decolonization efforts around the world, upon which it modeled itself. ${ }^{20}$ In so doing, it helped to render legible for the left the indeterminacy of "Black Power," providing it with a theory of oppression rooted in the armed guerilla tactics of the anti-imperialist Third World. ${ }^{21}$ With the help of new media technologies and within the context of an emerging consciousness of black identity as "oppositional," the Panthers became a Marxist-Leninist modeled vanguard, whose disruptions enabled new hegemonic "equivalences."22

The immediate impetus compelling Newton to issue his official declaration of support for the self-determination of homosexuals in August of 1970 apparently came from the French novelist Jean Genet, who spent several weeks tracking and interviewing the Panthers that year. The "avowed homosexual" Genet encouraged Newton to reconsider the presence of misogyny and homophobia within the Panthers, which moved Newton to call for an unprecedented coalition between black and gay liberation. ${ }^{23}$ Marc Stein has added that part of 
the glue suturing Newton's relationship with gay liberation was its erotic, homosocial quality - Newton's alliance letter appeared alongside of a photo of his shirtless body in Philadelphia's Plain Dealer. ${ }^{24}$

Still, Newton remained hesitant about fully embracing gay rights, which he continued to see as a "white" issue, and the precarious alliance he advanced proved in the end to be short-lived. ${ }^{25}$ His embrace of a broadly constituted, anti-Fascist "popular front" against issues like police oppression, which he and Bobby Seale had originally associated with the local black community, gained the Panthers material benefits but would cost them key advocates among black nationalists. The Panthers' ostensible white partners, in turn, often viewed the Panther leadership skeptically, culminating in instances of betrayal. These unintended consequences would aid in ultimately dismantling Newton's fragile coalition. $^{26}$

\section{The Sartorial Revolutionary: Rivera's Trans-gressive Body}

As a homeless transvestite of color, Rivera was not only predisposed to champion Newton's and others' post-68 calls to hegemonic, revolutionary action, she viewed her very body as inherently revolutionary. ${ }^{27}$ Through their sartorial disruptions of gender binaries, transvestites like Rivera "liberated" bathrooms and streets on a daily basis. According to Rivera, their so-called "criminal impersonations" dated back at least to the Boston Tea Party, in which American colonists dressed as Mohawks to assert their British liberties. ${ }^{28}$ Throughout her life, Rivera would see in transvestitism this kind of generative potential for social upheaval. ${ }^{29}$

Yet transvestitism was also personally and politically liberating for Rivera. In her "Spanish" upbringing, effeminate boys were automatically labeled "fags." 30 As Rivera explains, you were either a "fag or a dyke. There was no inbetween." 31 At the age of ten, Rivera fled from her abusive, racist, and homophobic grandmother, with whom she had been living in the Lower East Side, and found a new family among the trans-hustler community of $42^{\text {nd }}$ Street, which took her in and officially christened her with a name of her choosing: "Sylvia Lee."32

While life on the street was oppressive too, revolving around prostitution, drugs, disease, constant police harassment, and the threat of violence from "johns," it also nurtured a sense of thrill and deep familial and romantic bonds among the 40 to 50 "queens" who worked the streets alongside young Rivera. ${ }^{33}$ Used to having the "living daylights" beaten out of them, Rivera and her fellow queens were a resilient bunch with "nothing to lose." They were ready for war — they would sit around in the Aristo Hotel on $43^{\text {rd }}$ Street and $6^{\text {th }}$ Avenue and 
"just dream — waiting for the revolution to come, hoping and wishing to be free." When it finally did happen, Rivera recalls, "We were there."34

\section{“We're the Pink Panthers!": The Stonewall Rebellion}

Police raids, such as the one on the Stonewall Inn in the early hours of 28 June 1969, were a routine experience for queer patrons. New York and other large cities employed "vice squads" to enforce laws against prostitution, gambling, narcotics, racketeering, homosexual activity, and transvestitism. ${ }^{35}$ Yet as Seymour Pine, the officer who led the raid on Stonewall that night, later recalled, "morals units" persecuted transvestites in particular because they violated a section of the penal code that dealt with masquerading. ${ }^{36}$ Understandably then, Rivera "always felt like the police were the real enemy." She expected them to treat her and her fellow queens "like animals." 37 Still, police raids usually followed a choreographed script in which police took payoffs from the Mafia members who ran the gay bars in exchange for lax enforcement - they would warn bar managers before raiding, make a few token arrests, and leave, allowing the bar to reopen later. 38

The otherwise routine raid of Stonewall, however, escalated into what felt, for Rivera leading the charge, like a full-scale rebellion, one driven largely by other working-class queens of color and gay "street people," who dwelled outside the bar and who were thus fighting in defense of their home. ${ }^{39}$ In terms of whether the events that transpired that night at Stonewall can be considered conscious revolution or spontaneous rioting is of course a matter of perspective and memory. While for the already radicalized Rivera, this may have seemed like a culminating moment of collective resistance, for other participants it was more like frenetic carnival. ${ }^{40}$ The atmosphere that full-moon night was already made particularly contentious by Judy Garland's recent death - a woman who symbolized for many queens a "somewhere over the rainbow," a possibility of a better future and whose life of hardship resonated with their own. ${ }^{41}$ With Garland gone, queens and street people took resistance into their own hands. While lined up outside the bar, they began throwing coins at police officers - a symbol of Mafia payoffs. Their coins soon became bottles, Molotov cocktails, and trashcans. Terrified, police officers barricaded themselves inside Stonewall and waited for backup, fending off an enraged crowd gathering outside from breaking in.

Some "rioters" like Rivera did see themselves as revolutionists engaged in broader battles — indeed, Rivera had been involved with civil rights, antiVietnam protests, and the women's movement before she started throwing bricks at the police at Stonewall. According to Rivera, the Stonewall patrons had been part of "many different movements," and their allegiance to one connected them with all the others. Rivera specifically names her prior work within "black civil 
rights" as the means through which she became involved with the emerging struggle for gay liberation. ${ }^{42}$ That night, the streets on which Rivera and others had been living rang with shouts of "Gay Power" and "We're the Pink Panthers!"43 "Before you knew it," Rivera claims, "thousands of fags and dykes" started coming out of the "woodwork like fucking roaches." They lit up the Village "like a Christmas tree." As Rivera avers, people were tired. It was their "time to join the revolution," to ally with preexisting movements. For Rivera, at least, Stonewall was thus a brief moment where pluralities congealed into a "hegemonic bloc" of militant action. To see "everybody united on one front, was beautiful, it was really beautiful." That same-sex lovers, in the following days, began kissing each other in broad daylight was evidence to Rivera that Stonewall had ignited a new liberation movement and a new kind of unity that she would spend the rest of her life fighting to maintain. ${ }^{44}$

\section{Early Activism: From “Gay Rights” to Broad Coalition}

While Stonewall inspired Rivera to believe in revolution, she was politically inactive for a few months immediately afterward, a period of lapse that Rivera in later interviews finds difficult to explain — as she told historian Martin Duberman, she was "not really sure" why she returned to New Jersey, where she was residing, after the events of Stonewall. In any case, her salient entrance into gay activism began the following year in 1970 when she joined the Gay Activist Alliance (GAA), a post-Stonewall organization she had discovered through a Gay Power newspaper. ${ }^{45}$ Rivera had faith that this organization would work toward the liberation of all people, not only homosexuals. ${ }^{46}$ Indeed, she wrote on behalf of GAA to her "sister queens," urging them to join GAA in order to help stop "all the discrimination and police harassment and to change laws for the Gays." All people, including those who "act different and wear make-up," were welcome in GAA, Rivera emphasized, and should come to the Church of the Holy Apostles on $28^{\text {th }}$ Street and $9^{\text {th }}$ Avenue for GAA meetings. ${ }^{47}$

While Rivera here indicates GAA's inclusivity, she tellingly signed her name "Ray," not "Sylvia" Rivera. ${ }^{48}$ Indeed, GAA was not always open to Rivera's transvestitism - she was asked for her "male" name when she came to its first meeting. Although Rivera stuck with GAA in order to lobby for the passage of the city's first gay rights bill and particularly to protect its inclusion of trans-identified people, she maintained wide-ranging aspirations to "change the world" and engage oppression on multiple fronts. ${ }^{49}$ She thus clashed with the group's gayspecific agenda and became especially disconcerted when she realized that she, herself, was becoming narrowly entrenched in gay rights issues. ${ }^{50}$ 
As Rivera grew more disillusioned with GAA, she found herself attracted to the Gay Liberation Front (GLF), a group that saw itself and the gay liberation effort in general as intrinsically imbricated with the Panthers and other social movements around the world. ${ }^{51}$ According to sociologist Stephen Cohen, GLF and STAR both viewed liberation as a "multi-issued, unified struggle of gays, Black Panthers, anti-war protestors, and leftists" seeking to achieve socioeconomic revolution. ${ }^{52}$ Queer activist-scholar Benjamin Shepard has even called STAR a "caucus of GLF," in addition to being one of the nation's first transgender rights organizations. ${ }^{53}$

STAR was still a distant dream, however, when Rivera first began working with GLF. She remembers meeting Bob Kohler and other members of GLF who showed up in greater numbers than GAA representatives at a court hearing she had on 21 May 1970 — she had been arrested while petitioning for the GAA's gay rights bill in April. ${ }^{54}$ She praised the GLF for protesting in front of the New York Times headquarters to call out the names of the Vietnam dead as well as its open support for the Panthers. Through GLF, Rivera could be the "revolutionist" she always wanted to be, giving everything to the "whole community," one ambiguously defined. ${ }^{55}$ She sought to use the GLF to galvanize revolution and guarantee liberty for all through an assemblage of "gay, straight, trans, black, yellow, green, purple, or whatever." 56

\section{Suturing a Black-Queer Alliance: The Black Panthers' Constitutional Convention}

In the summer preceding Rivera's founding of STAR, the Black Panthers made a radical move to embrace feminist agendas, gay liberation, and other social movements. Like the GLF, they had begun to construct a "hegemonic bloc" of subordinated groups. Even before Huey Newton issued his now famous manifesto of alliance, the Panthers met at Howard University in Washington DC, on 8 and 9 August, to plan for a Revolutionary People's Constitutional Convention (RPCC) to be held that September in Philadelphia. Present at this planning meeting were "welfare mothers, doctors, lawyers, journalists, students, tenant farmers, greasers from Chicago, Latin Americans, high school students, gays, and concerned individuals." 57 As one white lesbian participant from New York, Lois Hart, recalls, Black Panther Afeni Shakur had called the Radicalesbians and GLF to DC as part of the Panthers' general effort to relate sexism and heterosexual oppression of women and gays with racism. For the Panthers, the "heaviest group of people dealing with racism," to place sexism at the core of oppression "energized and inspired each gay woman and man rolling toward Washington.” Hart regarded Newton's proposed alliance manifesto as a harbinger of a "human connection" that crossed race and gender. She maintained hope that the discipline of the Panther Party and the Panthers' own 
experiences of discrimination would help them relate to women and gay people. In turn, she wondered if she could similarly affect the Panthers by engaging them through the Third World Gay Revolution group. All in all, Hart believed the "constitution" they drafted in DC proved that oppressed people could in fact come together and transcend their "individual limitations." They could express an "emerging consciousness" that circumvented "THE MAN."58

An estimated crowd of 10-15000 people congregated at Temple University in Philadelphia in early September for the Panthers' RPCC. The Convention's aim was to redraft the original American Constitution and provide "authentic liberty and justice for all." 59 Delegates to the RPCC represented an array of movements - the American Indian Movement, Brown Berets, Young Lords, I Wor Keun (a NYC-based Asian American group), SDS-Worker-Student Alliance (SDS-WSA), GLF, and feminist groups. These various organizations viewed the Panthers as the "vanguard" of the liberation movement. ${ }^{60}$ As sociologist George Katsiaficas recalls, gay contingents were especially strong. At the plenary session on 6 September, hundreds of gay people entered the upper balcony of Temple's McGonigle Hall, chanting and clapping, "Gay, gay power to the gay, gay people! Power to the people! Black, black power to the black, black people!" Soon, "everyone rose to their [sic] feet and joined in," adding other subjectivities: Red, Brown, Women, Youth, and Student. When Michael Tabor, a Panther involved in the ongoing New York 21 conspiracy trials, opened the plenary with a two-hour speech, he made clear that the current Constitution excluded indentured servants, black slaves, Indians, and women, and that it said nothing about "sexual minorities." For Katsiaficas, Newton's order to "respect gays and feminists" was "essential to our unity." At the Convention's conclusion, delegates called for such "queer" demands as alternatives to the nuclear family, the right to be "gay, anytime, anyplace," and the affirmation of "sexual self-determination" for women and homosexuals. ${ }^{61}$

While gay people, particularly the radical lesbians, viewed the Convention critically, many found in the Panthers a willing ally. The New York Lesbians had concluded from the RPCC that the women's struggle could not take place within contexts like that of the Panthers, defined by "sexist male mentalities." While they had been pleased with Newton's call for solidarity and "dug" the speech he gave, which frequently referenced women and homosexuals, they were disturbed by its overall "superficiality." The speech lacked a "real awareness" of the oppression women and gays faced, and the inclusion of these groups within the Panther umbrella felt tacked on. Despite Newton's gesture to coalition, after all, he still privileged the independence of "black manhood". The lesbians' convention demands, moreover, were not included in the finalized reports. ${ }^{62}$ As lesbian activist Martha Shelley pointed out, the Panther leadership continued to view the role of Panther women as limited to bearing "revolutionary babies." As Shelley explained, gay men were treated relatively well at the 
Convention because they merely asked to fight alongside the Panthers, whereas the feminists and radical lesbians in attendance sought to usurp control over the means of production, industry, and their own destinies. ${ }^{63}$

Indeed, supporting Shelley's contention, the gay men of Chicago Gay Liberation (CGL) regarded the Panthers favorably as the first national organization to offer warm, public support to gay liberation while other "Marxist" groups persistently ostracized them. Invoking the iconic epistemology of Malcolm X, the CGL was determined to confront American imperialism by "any means necessary," particularly through a broad alliance of all it repressed. ${ }^{64}$ An anonymous "gay man" from Philadelphia denounced in Come Out! the treatment of lesbians at the RPCC but still recognized as a "vanguard revolutionary action" Newton's statement on Women's and Gay Liberation. For him, the Black Panther Party decidedly remained the "vanguard of the people's revolution in Amerikkka." 65

\section{Transvestite Power: The Rise of STAR}

Although Rivera did not attend the Panthers' convention in Philadelphia, she would have certainly been informed about its attempt to build coalition with Women's and Gay Liberation. Indeed, she had already admired Newton for his earlier declaration of support and would have tracked his initiatives in gay periodicals like Come Out!, which covered the Convention in detail and to which she contributed articles. Rivera would later visit DC in November for the follow-up convention to the one held in Philadelphia. Additionally, Rivera had strong connections with many of the New York-based gay activists who had gone to Philadelphia, including Martha Shelley, who protested alongside Rivera against New York University's (NYU's) homophobic policies in the weeks that followed the RPCC.

The sit-in that took place at NYU's Weinstein residence hall, 20-25 September 1970, provided the immediate context out of which Rivera established STAR. The sitting-in of a diverse sampling of NYU's student body and NYC's queer community — Gay Student Liberation (GSL), GLF, Christopher Street Liberation Day Committee, Red Butterfly, Gay Youth, NYU Women's Liberation, NYU Liberation Front, Transcendental Students, and of course Rivera and the street queens - was set off when the University administration decided to cancel dances to be held at Weinstein upon discovering they were "homosexual" events. ${ }^{66}$ For Rivera, the Weinstein sit-in was another "beautiful" moment of heterogeneous comingling. On the second day, Rivera was found rapping "autonomy" with a female student while others sang folk songs and "enlightened" each other. Students donated money and brought protestors food from the cafeteria. ${ }^{67} \mathrm{~A}$ Weinstein house vote revealed that students backed the protestors by a two-to-one margin and agreed unanimously to keep the police from intervening. ${ }^{6} 8$ 
For GSL member Ellen Broidy, the sit-in was an attempt to construct a "revolutionary community" that could stand outside the oppressive "System" of imperialism, racism, and sexism and recognize it as a common enemy. ${ }^{69}$ The GSL asserted the "beautifully revolutionary" idea: "gay is good." Homosexuality offered a means of freedom from the "straight jacket" imposed by "this fuckedup heterosexual society." Ultimately, the University called in the Tactical Police Force to evict the 29 remaining squatters. While they left peacefully, they and others returned that night, and "revolution" erupted once again across the University streets. Students began shouting, "Power to the people! Gay Power!" Others chanted: "The streets belong to the people, the University belongs to the people ... join the revolution." Predictably, the police reacted with force; apparently a plainclothes officer pointed a pistol at Rivera. Enraged, Rivera led a protest procession down $8^{\text {th }}$ Street to Sheridan Square, the site of Stonewall, and back to Weinstein, located on University Place. True to Rivera's hegemonic vision of revolution, this eclectic procession included "gays, straights, street people, transvestites, middle-class people, [and] college kids" dancing to "power to the people." 70

The eviction from Weinstein, which shattered a moment of "beautiful" coalescence, pushed Rivera to found STAR. ${ }^{71}$ About one week following the eviction, Rivera was already swearing that she and her new organization, STAR, would be back at Weinstein before the end of the term to assert their rights. ${ }^{72}$ STAR developed out of Rivera's short-lived Street Transvestites for Gay Power (STGP). Rivera issued her STGP manifesto immediately following the Weinstein eviction. ${ }^{73}$ Here, she encouraged Gay Liberation to take a more militant stance to achieving Gay Power. Rivera specifically called for a sustained "fight" against police "pig power" that would not cease until full rights for sexual minorities were secured. ${ }^{74}$

Rivera's targeting of "pig power" ought to be placed not only within the immediate context of Weinstein; it also coincided with a national escalation of police brutality against what the FBI, following the Panthers' RPCC in Philadelphia, had declared to be a homosexual-Panther coalition. Indeed, police in Philadelphia, days before the Convention, had raided Panther offices in West and North Philadelphia and Germantown, arresting five women and ten men, some of whom were strip-searched and pictured naked alongside armed police officers in local and national newspapers. ${ }^{75}$ This series of oppressive, antiPanther police efforts sparked an intensive uproar across the country against "pig power," which Rivera no doubt sought to harness a few weeks later following the Weinstein eviction in her attempt to distinguish and establish "street transvestites" as a political entity from within the discursive milieu of "gay power." 
Despite her persistent desire for alliance, Rivera understood that transidentified people needed their own groups to address their particular issues. Street transvestites remained heavily marginalized within straight and gay communities alike. ${ }^{76}$ Rivera recalls that, at the time she and her fellow trans-activist Marsha P. Johnson founded STAR, they and other street queens were residing in cramped hotel rooms. ${ }^{77}$ They had to find a livable space to shelter themselves and other street "kids" and queens, who were coming to dwell with them from "all over" the country — from Boston to California. ${ }^{78}$

Like the Panthers and the Young Lords, STAR endeavored to address the material, daily needs of its community. According to Susan Stryker, it was an overtly politicized version of the "house" culture typically found in black and Latino queer kinship networks, a place where trans youth of color could find a free and safe place to eat and sleep. ${ }^{79}$ The precursor to the STAR house was a tractor-trailer that housed about twenty street transvestites, which Rivera and Johnson supported through their hustling income. ${ }^{80}$ STAR found its next residence within a run-down, Mafia-owned building at 213 East $2^{\text {nd }}$ Street - GLF and Gay Youth co-hosted dances with STAR to raise rent funds. Rivera, Johnson, and the other "mothers" prostituted themselves to feed and clothe their "kids" (most of whom were older than Rivera) and keep them off the street. The "kids," in turn, would steal food when they could and as such kept the house fully stocked. For the roughly two years of STAR's existence, Rivera claims, "everyone had fun." 81 According to GAA journalist Arthur Bell, this multiracial, transvestite tenement commune became the "most interesting and lively house in New York." 82 In addition, STAR chapters rose up outside NYC in Chicago, California, and England. ${ }^{83}$

Yet STAR and its house were at the same time always about more than shelter and daily survival. It provided a safe-space for trans of color youth to express gender freely and addressed injustices related to prison conditions, police harassment, and anti-trans discrimination in mental health institutions, housing, and employment. ${ }^{84}$ While STAR was never large or well organized, historian Michael Bronski suggests it did not have to be in the early 1970s — it was a pioneering trans support group and a "political action nexus." 85 Combining the Maoist "self-defense" sentiments found in the original Panther Party platform of 1966 with the Party's more revolutionary socialist stance articulated at the RPCC, STAR proclaimed itself to be a "revolutionary group" that advocated "picking up the gun" if necessary in order to liberate "gay people," literally from jails as well as metaphorically within society, and to ensure simultaneously that "other people" have free and equal rights in America. ${ }^{86}$ Indeed, STAR's official platform, while first stressing the need to protect interests specific to transvestites and gay street people, ended with a call to establish an all-encompassing "revolu- 
tionary people's government," where "transvestites, street people, women, homosexuals, blacks, Puerto Ricans, Indians, and all oppressed people are free." 87 STAR embraced a "radical politics" and a philosophy to "destroy the system that's fucking us [all] over." 88

The more conservative GAA did little to help with STAR. It refused to even lend Rivera stereo equipment for the first STAR dance to be held 21 November 1970, explaining that it was not a "rental business." 89 Despite the GAA's prior commitment to help paint and fix up the dilapidated STAR house, Bob Kohler of GLF was the only volunteer to show up. ${ }^{90}$ Rivera, by this point, had cut most ties to GAA. Through GLF she had entryway to organizations like the Panthers, to which GLF donated funds, and other social movements that remained central to STAR's platform. Indeed, Arthur Bell noted that hanging on the walls of STAR house were posters urging the liberation of "All Political Prisoners" and the freeing of "Angela Davis," a Panther on trial at the time for kidnapping and murder. ${ }^{91}$

STAR became a beloved institution in the Lower East Side. It supported the broader community through its willingness to babysit neighborhood children and feed the hungry, a "revolutionary" effort, like that of the Panthers, based on community control initiatives to provide bread, housing, and clothing to the locally oppressed. ${ }^{92}$ Also in line with the Panther agenda, Rivera had hoped to grant educational opportunities to her "kids" by turning the top floor of STAR house into a school, but the gay teachers who had promised to volunteer failed to do so. ${ }^{93}$ Still, STAR succeeded in providing pivotal support space for queer of color youths like Chris Thompson, a black male transvestite who was enduring mistreatment at Bellevue Hospital. He had gone there for asthma treatment but was soon transferred to the psychiatric wing. When Rivera and Bell interviewed Thompson, he asserted his support for the new STAR group. Thompson described STAR's efforts as "beautiful" and claimed he would give his life to fight for gay people. ${ }^{94}$

STAR expanded its community reach by helping to found, along with GLF, a Gay Community Center at 130 West $3^{\text {rd }}$ Street. The Center secured space for queer people to socialize, hold classes, and discuss personal issues; it offered day care, a free food program, a gay switchboard and legal, medical, housing, and employment aid. ${ }^{95}$ In January of 1971, Rivera and gay activists met at the Center to organize a Gay Community Prison Committee to support queer prisoner rights. ${ }^{96}$

\section{STAR and the Panthers Come Together: The RPCC in DC}

Rivera's brief meeting with Huey Newton at the RPCC in DC symbolized the face-to-face conjoining of two movements — trans rights and the Black 
Panthers, which had been indirectly influencing and supporting each other at least since Stonewall for the former and since August of 1970 for the latter. This coming together remained one of Rivera's fondest memories. The Philadelphia convention had been one part of a two-part series. A subsequent convention met in DC on 27 November 1970, to ratify and implement the constitution drafted in Philadelphia. An estimated 7,500 arrived in DC that Thanksgiving weekend but were disappointed to find that most of the planned events did not materialize — the Panthers apparently refused to pay the full rent at Howard University, where the plenary was scheduled to take place. ${ }^{97}$

Still, attending the Convention was a landmark moment in Rivera's life. She embezzled STAR funds to go to DC with a current boyfriend. All the other gay groups from New York had sent representatives down, Rivera rationalized, so STAR had to be there too. ${ }^{98}$ Dan Smith of NY-GLF crocheted 69 colorful berets, which made the gay delegates easy to spot. ${ }^{99}$ Some of these were lavender, gold, and red, but Rivera's was entirely lavender. Sporting her GLF-Panther beret, Rivera found herself lost at the Convention amongst "bearded," "radical" men before she stumbled across Newton. Newton made sure Rivera knew that the Panthers had "accepted" her, to which Rivera replied that she knew and had, through GLF, always given money to the "Black Panther movement." Rivera was especially impressed by Newton's speech, which reiterated the BPP's inclusion of gays in the revolution. Hearing Newton speak was such a "great moving moment" for Rivera that she had to step outside to get fresh air. 100

An undated, anonymous City article, within the Arthur Bell papers at the New York Public Library, named STAR as one group present at the DC convention along with GLF and Third World Gay Revolution. According to the article, this particular convention was the backdrop for the "largest gathering of homosexuals" since Stonewall. The presence of so many gay people from across the country stimulated a sense of national solidarity and the need to advocate beyond isolated interests. That such solidarity was directly inspired by the Panthers is made clear in the "16 Point Platform and Program" that the Third World Gay Revolution drafted and adopted as the basis for a national gay liberation agenda. ${ }^{101}$ Its demands for "decent and free housing, fit shelter for human beings" draws nearly verbatim from the Panthers' Ten-Point Program of 1966. Its calls for an end to the "fascist police force" and the exemption of gay men from compulsory military service also echo the Panthers' original platform. Yet its tenth demand for the release of all Third World, gay, and political prisoners from jails and mental institutions is a more radical update of the Panthers' initial proposal to retry black prisoners via a jury of their peers. It reflects more closely the Panthers' stance articulated in the Philadelphia convention that all prisoners should be judged anew by decentralized revolutionary tribunals. ${ }^{102}$ 


\section{Hegemony Fragmented: STAR's Decline}

The Panthers' constitutional conventions manifested a culmination of its efforts to ally with Women's and Gay Liberation and helped to establish groups like STAR and Gay Liberation itself. The deterioration of this coalition, in turn, coincided with the decline of the former and the fragmentation of the latter. According to George Katsiaficas, Newton, already expressing reluctance in September to hold the Philadelphia convention, had undergone a full-fledged change of heart concerning the broad-alliance initiative by the time he got to the DC convention. For this reason, he called off many of the scheduled events in DC, promising disappointed delegates a "rain check" for a future convention. For Katsiaficas, DC heralded Newton's abortion of the heterogeneous alliance queer revolutionaries like Rivera had so praised him for instituting. ${ }^{103}$

As the Panther alliance disintegrated almost as fast as it had appeared, Rivera found herself struggling to keep STAR and trans-rights issues pertinent within the mainstream gay rights movement. ${ }^{104}$ By 1971, the STAR residents had been evicted from their $2^{\text {nd }}$ Street location for failure to pay rent, and the GLF had gone into decline, leaving the more conservative, assimilationist GAA as NYC's primary gay rights group. The GAA, which espoused a narrow form of gay identity politics and whose members were planning to run for public office, soon dropped protections for transvestites and drag queens from the citywide gay rights ordinance for which Rivera had lobbied assiduously in the spring of 1970. ${ }^{105}$

In Washington Square Park in 1973, on the annual Christopher Street Liberation Day commemorating Stonewall, Rivera got into a physical fight with Jean O'Leary and other Radicalesbians, who had successfully blocked drag queens from performing - they believed drag endorsed sexist portrayals of women. Although they attempted to stop Rivera from speaking, beating her so badly that she ended up needing 60 stitches, Rivera forced her way on stage anyway. ${ }^{106}$ After this violent attack from people she once considered allies, Rivera largely disappeared from the movement and did not resurface until Martin Duberman interviewed her in 1990 for his groundbreaking Stonewall. The incident of 1973 made clear to Rivera that trans-identified people still occupied a marginalized place within the gay rights struggle. As Rivera puts it, "They fucked me. They fucked my community" despite all that queens had done to inspire the movement in the first place. ${ }^{107}$ In the speech a breathless Rivera gave that day in 1973, she declared that she no longer believed in revolution, in the promise of radical social upheaval, but she still believed in Gay Power - a Panther-influenced concept of localized power sustained through unity, militancy against state forces, and community infrastructures. ${ }^{108}$ 
Immediate and general factors contributed to this apparent collapse of revolutionary unity. According to George Katsiaficas, it remains unclear as to why exactly Huey Newton began to distance himself from the remarkable alliance he had compelled. Newton may have been trying to reorient the Panthers back to black communities, from which they had drifted during his incarceration under Minister of Information Eldridge Cleaver's leadership, but scholars have also speculated that increasing pressure from the FBI and CIA encouraged Newton's sudden disavowal of radical hegemony. ${ }^{109}$ As Winston A. Grady-Willis has pointed out, the FBI, in an effective attempt to shatter the Panthers' newfound partnership with Gay Liberation in 1970, mailed forged letters from fictitious Panther supporters to Chief of Staff David Hilliard protesting Newton's August statement of support. Following the RPCC in DC in November of that year, the FBI mailed a bogus letter from a member of SDSWSA, which declared SDS-WSA's rejection of the BPP as the vanguard of the revolutionary movement. This slew of fake and forged Panther letters was part of a concerted effort started in March of 1970 to divide the Party leadership. It threw the Party into internal chaos and an atmosphere of constant distrust, which culminated in its factional split in 1971 between a Newton-led camp, favoring community programs, and another centered around Eldridge Cleaver, who endorsed guerilla warfare tactics. ${ }^{110}$

Marc Stein has also pointed to the high level of tension that existed between the Panthers and gay liberationists regarding the specific issue of the nuclear family. As Stein explains, while straight activists of color sought to defend their families as sources of strength against white supremacist attempts to pathologize and discredit them, feminists and gay activists often demeaned the family as a patriarchal locus of oppression. ${ }^{111}$ At the RPCC in DC, for example, 700 women passed a resolution backing the Panthers and Women's Liberation but attacked the actions of lesbian feminists in Philadelphia for their desire to abolish the nuclear family, a "savagely uprooted" institution in the lives of black women. Black women, they claimed, had little in common with these white, middle-class lesbians and as such tended to prioritize anti-racism over anti-sexism. ${ }^{112}$

One can also explain the fragmentation of the Panthers-centered hegemony, however, in a more general way. Indeed, hegemonic articulations like "Power to the People," as Laclau and Mouffe have implied, involve fleeting moments of synthesis across a plurality of equivalences that ultimately beget the strengthening, not blurring, of particular autonomies like "trans identity." This ephemeral quality of radical democracy stems in part from the contradictions inherent in the modern imperialist state and the US Cold War welfare state specifically, which sought to distinguish and marginalize its citizenry under Manichean categories of its own making, like "colonizer" and "colonized," while 
at the same time subsuming these "otherized" subjectivities via universalist principles of liberty and equality. The presence of marginalized people and the systematic reproduction of their marginalization helped stabilize norms of modern citizenship, characteristic of a welfare state like that of the postwar US - a state meant to cater to the interests of a presumably homogeneous domestic body. ${ }^{113}$

As Ann Stoler and Frederick Cooper explain, imperial welfare states like the US after WWII transitioned from embracing agendas of "civilization" to ones of "development," a discourse articulated by the US not only in Vietnam but also with regard to non-normatively gendered people, who were to be "reformed" through the regulatory practices of the vice squads and mental institutions. ${ }^{114}$ The US imperialist state thus sought to "include" queer people within its polity through homogenizing efforts of disciplinary reform that simultaneously reproduced their marginalization as different - a difference needed in part to maintain the heterosexual sanctity of the postwar nuclear family.

Post-68 activists sought to take advantage of, and work within, these paradoxical discourses of the imperialist state, voicing such perplexing claims as "popular sovereignty," which as political theorist Wendy Brown has noted attempts to use an essentialist conception of absolute power, "sovereignty," as a means to achieving the political freedom of a dispersive demos. ${ }^{115}$ As such, activists enjoyed moments of hegemony, but these moments were short-lived because they were based on paradoxical claims, whose contradictions could be employed to critique the state but could also spur the fragmentation of their solidarity. Alongside other groups, for instance, sexual minorities attempted to invoke a common sense of subordination as a means to eventual inclusion within a revolutionized state - yet their subordinate social location was already the mode of their civic inclusion. While they briefly united against a "Man," a distinct, "colonial" state power and constituted for themselves a "Power to the People," their revolutionary declaration of commonality could only remain revolutionary by reproducing and dwelling within the marginalization it critiqued. In the end, rather than include them within an expanded welfare state, the US government dismantled its welfare state, adopted neoliberal policies, and coupled them with violent efforts that heavily targeted the Black Panthers; it thereby incentivized the dispersal and further disfranchisement of the "people," who in turn came to privilege particularity over alliance.

\section{Legacy: Trans Subjectivity and Power}

While the STAR organization was certainly short-lived, it arose from a brief moment of hegemonic coalition that followed in the wake of the 
Stonewall Rebellion and the sentiments of revolutionary, pluralist unity that Stonewall inspired. The Panthers' declaration of a "popular front" alliance of sorts with Women's and Gay Liberation in the summer and fall of 1970 epitomized the implementation of the kind of unity politics Rivera saw at Stonewall and hoped could effect the long-desired, post-68 revolution. Organizations like GLF, which shared close ties with the Panthers, and demonstrations like the Weinstein sit-in similarly reflected and inculcated the coalitionary spirit Rivera admired in Huey Newton. Recognizing at the same time, as the Panthers did, that in addition to advocating for disparate struggles, one's own community had particular needs to be addressed, she and Marsha Johnson founded STAR, a community group that provided for the material and political demands of street transvestites of color while still calling for a "revolutionary people's government" that would represent the interests of all those oppressed.

Out of this fleeting "hegemonic" moment of pluralist-unity, Rivera helped to constitute and sustain trans identity as an autonomous sociopolitical subjectivity. Whereas before STAR, "trans" people did not exist — they were regarded as "drag queens," STAR gave non-traditional gender expression a formal platform that helped to legitimize and nuance transgender identities. ${ }^{116}$ Some have even considered STAR the nation's first transgender rights group. The STAR house became an indirect model for Transy House, still in existence in Brooklyn, where Rivera lived out her later years. ${ }^{117}$ In 1999, Rivera was invited to address the World Pride Rally in Rome, where 500000 "beautiful, liberated gay men, women, and trans people" finally gave her the respect she long deserved but could "never" get in the United States - they called her "the mother of the world's transgender movement and the gay liberation movement." 118 In 2001, following the murder of trans sex worker Amanda Milan in NYC, Rivera reinstituted STAR, changing the "T" from "transvestite" to "transgender." 119 Yet STAR died with Rivera the following year, who succumbed to liver cancer brought on by years of alcoholism. While Rivera, literally from her deathbed, met with members of the Empire State Pride Agenda (ESPA) to fight for the inclusion of trans people within New York's Sexual Orientation Non-Discrimination Act, the legislation, initially drafted in 1971 when STAR was first active, passed that year without protections for gender identity and expression. ${ }^{120}$ Rivera's lifelong struggle thus continues without her today on a multiplicity of trans advocacy fronts, including ESPA's ongoing effort to pass the Gender Expression Non-Discrimination Act through the New York State Senate — it has passed the Assembly five consecutive times since 2008. That the bill was first introduced to the Senate and Assembly in 2003, just a year after her death, speaks to Rivera's tremendous accomplishments as well as the extent of work left to do to realize her dream of trans empowerment and universal equality. ${ }^{121}$ 


\section{NOTES}

1 Sylvia Rivera, interview by Martin Duberman, 14 October 1990, Audiotape 02890. Credit: Martin B. Duberman Papers. Manuscripts and Archives Division. The New York Public Library (NYPL). Astor, Lenox, and Tilden Foundations (hereafter referred to as Duberman Papers).

2 Just three months prior to the circulation of this statement, a Gay Liberation Front activist had spoken at a Black Panther rally in New Haven, Connecticut, not only to support black liberation but also to admonish the Panthers for their openly homophobic articulations. Indeed, Panther Minister of Information Eldridge Cleaver's Soul On Ice, published two years earlier, associated homosexuality with passivity, sickness, and even "baby-rape." Seen in this context, Newton's declaration was a radically progressive show of support for Women's and Gay Liberation. It still, however, highlighted Newton's own struggles to overcome homophobic and sexist sentiments. In speaking to his fellow Panthers, Newton suggested that despite his and their own "insecurities about homosexuality and the various liberation movements among homosexuals and women," in which "our first instinct is to want to hit a homosexual in the mouth, and want a woman to be quiet," the Party should attempt to "unite with [these movements] in a revolutionary fashion." See Merle Woo, "Stonewall Was a Riot - Now We Need a Revolution," in Smash the Church, Smash the Statel: The Early Years of Gay Liberation, ed. by Tommi Avicolli Mecca (San Francisco: City Lights Publishers, 2009), 285; Eldridge Cleaver, Soul On Ice (1968, repr.; New York: Delta Trade Paperbacks, 1999), 127-28, 136; Huey P. Newton, “The Women's Liberation and Gay Liberation Movements," available from http://historyisaweapon.org/defcon1/newtonq.html [accessed 5 March 2012]. I capitalize "Women's and Gay Liberation" to refer to specific movements of the time and use lower-case titles to denote these efforts more generally.

3 According to Newton, "We want to hit a homosexual in the mouth because we are afraid that we might be homosexual." See Newton, "The Women's Liberation and Gay Liberation Movements"; Nikhil Pal Singh, "The Black Panthers and the 'Undeveloped Country' of the Left," in The Black Panther Party Reconsidered, ed. by Charles E. Jones (Baltimore: Black Classic Press, 1998), 35; Marc Stein, City of Sisterly and Brotherly Loves: Lesbian and Gay Philadelphia, 1945-1972 (Chicago: University of Chicago Press, 2000), 332.

${ }^{4}$ See, for instance, Judson L. Jeffries, Huey P. Newton: The Radical Theorist (Jackson: University of Mississippi Press, 2006), 26.

5 According to Joanne Meyerowitz, the discourse pertaining to "transsexuality" 
emerged in the US in the mid-twentieth century as doctors began to define it as a new sexological category that included some of the "inverts" left out of narrower definitions of "homosexuality" and "transvestitism." Well into the 1960s, however, the distinctions of these taxonomies remained vague and were determined largely through negotiations between doctors and patients. The "sexual revolutions" of the late 1960s saw the sexualization of MTF (male-to-female) transsexuals seeping into mainstream culture. MTFs were now more commonly talking about their sex lives, posing for erotic photos, organizing as minority groups demanding rights, and challenging legal systems to define new borders for sex, gender, and sexuality, including transsexuality. While Rivera did not consider herself a "transsexual," her "transvestite" activism took place within this period of nascent transsexual political organizing and collective activism. See Joanne Meyerowitz, How Sex Changed: A History of Transsexuality in the United States (Cambridge: Harvard University Press, 2002), 170-76, 202, 207, 227. By the early 1990s, the term "transgender" had developed as an umbrella term for anyone challenging the boundaries of sex and gender. See Leslie Feinberg, Transgender Warriors: Making History from Joan of Arc to RuPaul (Boston: Beacon Press, 1996), x. In this paper, I use the more ambiguous term, "trans," to refer to an inchoate, expanding discourse not yet explicitly indexed as "transgender." I also tend to describe the discursive events pertaining to the upheaval of "Stonewall" as a "rebellion," not a "riot," simply because Rivera persistently viewed Stonewall in this way, as a consciously organized form of resistance. As will be discussed later, contemporaries expressed a multiplicity of conflicting perspectives regarding Stonewall.

${ }^{6}$ See Stephen L. Cohen, The Gay Liberation Youth Movement in New York: "An Army of Lovers Cannot Fail” (New York: Routledge, 2008), 131. See also Jessi Gan, "'Still at the Back of the Bus': Sylvia Rivera's Struggle," Centro Journal XIX, no. 1 (2007): 124-139.

${ }^{7}$ See Layli Phillips and Shomari Olugbala, "Sylvia Rivera: Fighting in Her Heels: Stonewall, Civil Rights, and Liberation," in The Human Tradition in the Civil Rights Movement, ed. by Susan M. Glisson (Lanham: Rowman \& Littlefield, 2006), 310$12,326$.

8 Ibid., 326. See also Rivera, interview by Duberman, 14 October 1990, Audiotape 02890, Duberman Papers.

9 Phillips and Olugbala, "Sylvia Rivera: Fighting in Her Heels," 326. In pointing to a long history of radical nationalism and anti-imperialism in twentieth-century Latin America, historian Lorrin Thomas has offered a critical corrective in her efforts to decenter the Black Panthers as the sole progenitor of radical politics for identity-based minority groups in this period. As Thomas contends, Puerto Rican youth activists who came of age in NYC in the early 1960s often drew upon a political discourse of "recognition" that dated back at least to the 1930s. 
See Lorrin Thomas, Puerto Rican Citizen: History and Political Identity in TwentiethCentury New York City (Chicago: University of Chicago Press, 2010), 203, 227.

10 Rivera, interview by Duberman, 14 October 1990, Audiotape 02890, Duberman Papers.

11 George Katsiaficas, "Organization and Movement: The Case of the Black Panther Party and the Revolutionary People's Constitutional Convention," 12; available online: http://www.eroseffect.com/articles/Rpcc.pdf. The essay appeared in Liberation, Imagination, and The Black Panther Party: A New Look at the Panthers and Their Legacy, ed., by Kathleen Cleaver and George Katsiaficas (New York: Routledge, 2001). See also Manning Marable, Race, Reform, and Rebellion: The Second Reconstruction and Beyond in Black. America, 1945-2006 (Jackson: University of Mississippi Press, 2007), 110. By the summer of 1969, the time of the Stonewall Rebellion, the Black Panthers had become the FBI's top concern. They were soon to be the target of 233 out of 295 total counterintelligence operations directed against African American political groups. See Winston A. Grady-Willis, "The Black Panther Party: State Repression and Political Prisoners," in The Black Panther Party Reconsidered, 366.

12 As political theorist Timothy Mitchell would claim, these activists took advantage of modern state power - its capacity to make the "state" appear as an organizing force distinct from an autonomous "people" precisely at the moment it becomes most integral within "civil society" — in their attempt to constitute and suture new alliances. See Timothy Mitchell, "Metaphors of Power," Theory and Society 19, no. 5 (October 1990): 572.

13 See Ernesto Laclau and Chantal Mouffe, Hegemony and Socialist Strategy: Towards a Radical Democratic Politics (1985, repr.; London: Verso, 2001), 149-193.

14 Ibid.

15 Floyd Hayes, III, and Francis A. Kiene, III, “'All Power to the People': The Political Thought of Huey P. Newton and The Black Panther Party," in The Black Panther Party Reconsidered, 160-61.

16 The Panthers began implementing community "survival" programs nationally late in 1968. This initiative heralded a general shift in the Party's official philosophy from one of paramilitary defense to one of community service. Such a shift, coupled with the exile of key male leaders, intensified efforts of state-sponsored repression, and the increasing involvement of and demands articulated by Panther women generated a new internal dialogue about the role of gender in the Party. Initially, the Party was an all-male organization, founded with the intention to rehabilitate black manhood. By 1969, however, Eldridge Cleaver, who had only the year before promoted the idea of "pussy power," regarding women's ability to withhold sex to compel men to political action, asserted, on behalf of the incarcerated Panther Ericka Huggins, "one of the earliest and strongest formulations by a male Panther of a nonsexual, revolutionary role" for 
black women, according to historian Tracye Matthews. The example set by Huggins and revolutionary Vietnamese women inspired other Panther women, interviewed in 1969, to claim that the Party's position had genuinely changed; both men and women were coming to realize that "in a proletarian revolution, the emancipation of women is primary." Historian Angela D. LeBlanc-Ernest has noted that as early as February of 1967, just one month after the Panthers' first office opened, a woman attended one of their biweekly meetings. Her presence pushed Bobby Seale to "make it clear" that "sisters could join the Black Panther Party." Kathleen Cleaver, who joined in November of that year, was the most prominent and influential woman during the early years of the BPP. Yet it was not until the Panthers expanded in 1968, in the wake of the "Free Huey Campaign," that women's participation in it mushroomed to encompass what Seale estimates to be sixty percent of the Party's membership. See Tracye Matthews, "No One Ever Asks, What a Man's Place in the Revolution Is': Gender and the Politics of the Black Panther Party 1966-1971," in The Black Panther Party Reconsidered, 277-78, 281, 284. See also Angela D. LeBlanc-Ernest, "'The Most Qualified Person to Handle the Job”: Black Panther Party Women, 1966-1982," in The Black Panther Party Reconsidered, 307-309.

17 Hayes and Kiene, "'All Power to the People," 165-66. Angela Davis has suggested that Malcolm X's international travels, which illuminated for him the centrality of women in a number of African countries and liberation movements, encouraged a philosophical shift in his thinking with respect to the position and empowerment of women in general. Just prior to his assassination in 1965, Patricia Hill Collins adds, Malcolm was beginning to grapple with how to implement gender-specific strategies for black community development. This fluctuation in Malcolm's thinking and praxis would have occurred only a few years prior to the founding of the Panthers, who upheld Malcolm as their ideological godfather. See Angela Y. Davis, "Meditations on the Legacy of Malcolm X," in Malcolm X: In Our Own Image, ed. by Joe Wood (New York: St. Martin’s Press, 1992), 39-40. See also Patricia Hill Collins, "Learning to Think for Ourselves: Malcolm X's Black Nationalism Reconsidered," in Malcolm X: In Our Own Image, 79 .

18 Kobena Mercer, Welcome to the Jungle: New Positions in Black Cultural Studies (New York: Routledge, 1994), 303.

19 Amy Abugo Ongiri, Spectacular Blackness: The Cultural Politics of the Black Power Movement and the Search for a Black. Aesthetic (Charlottesville: University of Virginia Press, 2010), 17.

20 Singh, "The Black Panthers and the 'Undeveloped Country' of the Left," 88. 21 Mercer, Welcome to the Jungle, 302-303.

22 The Panthers were recognized to be the most progressive organization in the black liberation struggle with regard to their gender and sexuality politics. They 
placed themselves in opposition to cultural nationalist groups, like Maulana Karenga's Us, whose explicit "male chauvinism" Bobby Seale denounced in a 1970 interview. See Matthews, "No One Ever Asks, What a Man's Place in the Revolution Is,"” 273.

23 Singh, "The Black Panthers and the 'Undeveloped Country' of the Left," 87. 24 Stein, City of Sisterly and Brotherly Loves, 332-33.

25 Newton's statement of alliance with Women's and Gay Liberation appears within the section "White America" in To Die for the People. See Huey P. Newton, To Die for the People: The Writings of Huey P. Newton (New York: Random House, 1972), 152-55.

26 Hayes and Kiene, "AAll Power to the People," 167.

27 Historian Betty Hillman has highlighted how early gay liberationists sought to mobilize the street queens' inherently "revolutionary" bodies. Mike Silverstein, for instance, a leader of Berkeley GLF, argued in Gay Sunshine, a Bay Area gay liberation publication appearing in 1970, that drag and street queens disarticulated the masculine-feminine gender binary that contributed to gay oppression. Just by walking down the street, Silverstein explained, a "Street Queen" refused to be either a man or a woman and that was "the most profoundly revolutionary act a homosexual can engage in." For Silverstein, queens were not only homosexuals; they embodied the rebellion that gay liberation aspired to achieve in dismantling gender roles and constructions of masculinity. See Betty Luther Hillman, "'The most profoundly revolutionary act a homosexual can engage in': Drag and the Politics of Gender Presentation in the San Francisco Gay Liberation Movement, 1964-1972," Journal of the History of Sexuality 20, no. 1 (January 2011): 172.

Indeed, Tim Retzloff has suggested that Rivera's radicalism was intricately affiliated with her distaste for labels and the overdetermination of her "body" - her darker skin, feminine performance, and sheer destitution — as a site of alterity that threatened normative homophile respectability, a site to be shunned or fetishized but not assimilated. See Tim Retzloff, "Eliding Trans Latino/a Queer Experience in U.S. LGBT History: José Sarria and Sylvia Rivera Reexamined," Centro Journal XIX, no. 1 (2007): 155.

28 Sylvia Rivera, "Transvestites: Your Half Sisters and Half Brothers of the Revolution," Come Out! 2, no. 8 (Winter 1972): 10. As Rivera's close friend and fellow transvestite activist Marsha P. Johnson explained, while "drag queens" dress in drag occasionally for balls, transvestites "live in drag." Transsexuals spend most of their lives in drag as well, but they often also receive hormone treatments and plan for a sex change. See Allen Young, "Rapping with a Street Transvestite Revolutionary: An Interview with Marcia Johnson," in Out of the Closets: Voices of Gay Liberation, ed. by Karla Jay and Allen Young (1972, repr.; New York: NYU Press, 1992), 119.

29 The Sons of Liberty, who threw British East India Company tea into the 
Boston Harbor in 1773, employed a form of drag to perform an act, whose "revolutionary" connotations Rivera generally associated with transvestitism. As Philip Deloria has explained, in dressing as Mohawks these colonists embodied an ambiguity — through their rhetorical theatricalization of the savagery and civilization that the native person represented as well as their attempt to assert a new American nationalist identity through an appeal to extant notions of British liberty — that highlighted the contingency of identity and social order and paved the way for new, literally revolutionary conceptions of belonging. Still, Deloria also makes clear that these colonists, in "playing Indian," assumed a kind of imperial privilege particularly available to white American men negotiating spaces of power through an enactment of tropes of savagery and civilization specific to the native person. In this way, the convictions of the Boston Tea Party participants differed greatly in kind from Rivera's, pertaining to the revolutionary potential of homeless and working-class, queer of color transvestites. See Philip Deloria, Playing Indian (New Haven: Yale University Press, 1998), 8, 32.

30 As scholar-filmmaker Frances Negrón-Muntaner has suggested, Rivera's Puerto Rican heritage and "boricua" body positioned her in a peculiarly contentious relationship within the Anglo-American, mainstream "gaze." According to Negrón-Muntaner, Puerto Rican ethno-national identity, while not a simple effect of colonial political domination, economic restructuring, interclass conflict, and symbolic violence, has as a "socially meaningful sign" been constituted "through and from these constraints." In NYC at this time, "boricuas" were relegated via the normative public gaze to social categories associated with the "feminine" and the shameful. See Frances Negrón-Muntaner and Rita Gonzalez, "Boricua Gazing: An Interview with Frances Negrón-Muntaner," Signs: Journal of Women in Culture and Society 30, no. 1 (2004): 1351-53. For more on the feminized "queerness" and shame of the Puerto Rican ethno-national subject see Laura Briggs, Reproducing Empire: Race, Sex, Science, and U.S. Imperialism in Puerto Rico (Berkeley: UC Press, 2002).

31 Gan, "'Still at the Back of the Bus," 129.

32 Rivera had always liked the name "Lee," and there were no other "Sylvias" working the strip at that time. See Phillips and Olugbala, "Sylvia Rivera: Fighting in Her Heels," 322. See also Sylvia Rivera, "Queens in Exile, The Forgotten Ones," in GenderQueer: Voices from Beyond the Sexual Binary, ed. by Joan Nestle, Clare Howell, and Riki Wilchins (Los Angeles: Alyson Books, 2002), 68.

33 According to literary critic, Samuel Delany, Times Square in this period included a multiplicity of spaces that fostered democratizing forms of interclass contact, informal, ephemeral interactions that were particularly critical for encouraging and sustaining relationships among marginalized, "gay"-identified people. See Samuel R. Delany, Times Square Red, Times Square Blue (New York: NYU Press, 1999), 123. 
34 David Isay and Harvey Wang, "Sylvia (Ray) Rivera and Deputy Inspector Seymour Pine: Veterans of the Stonewall Riots New York City," in Holding On: Dreamers, Visionaries, Eccentrics, and Other American Heroes (New York: W.W. Norton, 1996), 74-75.

35 Phillips and Olugbala, "Sylvia Rivera: Fighting in Her Heels," 315.

36 Isay and Wang, "Sylvia (Ray) Rivera and Deputy Inspector Seymour Pine," 7778. According to Pine, transvestites violated section 240.35, paragraph 4, which referred to anyone "being masked or in any manner disguised by unusual or unnatural attire or facial alteration, [who] loiters, remains or congregates in a public place with other people so masked or disguised, or knowingly permits or aids persons so masked or disguised to congregate in a public place; except that such conduct is not unlawful when it occurs in connection with a masquerade party or like entertainment." As Pine explains, Stonewall, like other gay bars in the city, was run by the Mafia. Pine's unit had been tipped off that the bar was being used to extort information from homosexuals working on Wall Street. The raid was apparently part of an effort to investigate this connection.

37 Sylvia Rivera, "I'm Glad I was in the Stonewall Riot," in Trans Liberation: Beyond Pink or Blue, ed. by Leslie Feinberg (Boston: Beacon Press, 1998), 106. 38 Phillips and Olugbala, "Sylvia Rivera: Fighting in Her Heels," 315.

39 As historian Susan Stryker makes clear, the Stonewall Rebellion was merely the largest and most consequential example of growing "transgender" activism. Similar outbursts of direct action against police had taken place at Cooper's Donuts, a coffeehouse in Los Angeles, in 1959 and at Compton's Cafeteria, in San Francisco, in 1966. See Susan Stryker, Transgender History (Berkeley: Seal Press, 2008), 82.

40 As activist Karla Jay recalls, the uprising at Stonewall seemed more like a "spontaneous upheaval" than a conscious and organized expression of political action. See Karla Jay, Tales of the Lavender Menace: A Memoir of Liberation (New York: Basic Books, 2000), 74-77. For a similar viewpoint see John Murphy, Homosexual Liberation: A Personal View (New York: Praeger Publishers, 1971), 93. Donn Teal suggests that on the first night, Stonewall rioters were enacting a vaguely understood form of "retribution"; it was not until the second night that a sense of "gay power" really coalesced. See Donn Teal, The Gay Militants (New York: Stein and Day Press, 1971), 21, 24. Writer Edmund White remembers how slogans like "gay is good," patterned off of "black is beautiful," sounded comically preposterous to many at Stonewall who had never before considered their homosexuality as a criteria for minority group status. See "A Conversation With...Edmund White and Doric Wilson," YouTube video, 7:38, posted by "itlmedia," 28 July 2009, http:/ / www.youtube.com/watch?v=0Ob-x3QoGfg. 41 Jay, Tales of the Lavender Menace, 72.

42 Rivera, interview by Duberman, 14 October 1990, Audiotape 02889, 
Duberman Papers.

43 Gan, "'Still at the Back of the Bus," 131-32.

44 Isay and Wang, "Sylvia (Ray) Rivera and Deputy Inspector Seymour Pine," 76;

Sylvia Rivera, Talk at Latino Gay Men of New York (LGMNY), June 2001, Lesbian and Gay Community Services Center, NYC, Centro Journal XIX, no. 1 (2007): 120; Gan, "Still at the Back of the Bus," 133.

45 Rivera, interview by Duberman, 14 October 1990, Audiotape 02889, Duberman Papers.

46 Arthur Bell, "Gay and Proud and Busted on 42," GAA News, 1970, NYPL, Manuscripts and Archives, International Gay Information Center Collection (IGIC), Papers of Arthur Bell, Box 93, Gay Power Scripts Folder (hereafter referred to as Bell Papers). Credit: Arthur Bell Papers. Manuscripts and Archives Division. The New York Public Library. Astor, Lenox, and Tilden Foundations.

47 Ray Rivera, note to Gay Power, Bell Papers, Box 93, Gay Power Scripts

Folder.

48 Ibid.

49 Rivera, "Queens in Exile," 79.

50 Rivera, interview by Duberman, 14 October 1990, Audiotape 02889, Duberman Papers.

51 Benjamin Shepard, "Sylvia and Sylvia's Children: A Battle for a Queer Public Space," in That's Revolting!: Queer Strategies for Resisting Assimilation (New York: Soft Skull Press, 2008), 125.

52 Cohen, The Gay Liberation Youth Movement in New York, 131.

53 Shepard, "Sylvia and Sylvia's Children," 126. In New York City and elsewhere, GLF support for "queens" and "transvestites" was limited too. While the GAA came to explicitly exclude trans people from its agenda, GLF, which trans people had worked to establish after Stonewall, soon made them feel unwelcome. Only later did gay liberation and feminism come to embrace more progressive understandings of the interplay of sexuality, orientation, and gender. As Michael Bronski has pointed out, female members of GLF viewed transvestitism skeptically, seeing it as a form of sexist male mockery. Gay writer-activist Perry Brass has highlighted as well the stark class divides that existed between the mostly middle- and upper-class, college-educated GLF members and the "STAR girls," who appeared "disruptive" in contrast to them. Due to tensions such as these, trans individuals like Rivera eventually felt the need to construct their own organizations, distinct from the "gay rights" movement. See Michael Bronski, “Sylvia Rivera: 1951-2002," in Z Magazine, April 2002; available online: http:/ / www.zcommunications.org/sylvia-rivera-1951-2002-by-michael-bronski; "Perry Brass STAR," YouTube video, 1:29, posted by “Ibranson1," 24 March 2010, http:/ / www.youtube.com/watch?v=DtJL35wGcEo; Stryker, Transgender History, 86. 
54 Rivera, interview by Duberman, 14 October 1990, Audiotape 02889, Duberman Papers.

55 Rivera, interview by Duberman, 14 October 1990, Audiotape 02890, Duberman Papers.

56 Rivera, "Queens in Exile," 80.

${ }^{57}$ Katsiaficas, "Organization and Movement," 14.

58 Lois Hart, "Black Panthers Call a Revolutionary Peoples' Constitutional

Convention: A White Lesbian Responds," Come Out! 1, no. 5 (September-

October 1970): 15.

59 Katsiaficas, "Organization and Movement," 2.

60 Ibid., 12. By 1970, SDS had become SDS-WSA.

61 Ibid., 15-17, 21.

62 "No Revolution Without Us," Come Out! 1, no. 5 (September-October 1970): 17.

63 Martha Shelley, "Subversion, Subversion," Come Out! 1, no. 7 (DecemberJanuary 1970): 8-9.

64 "Working Paper for the Revolutionary People's Constitutional Convention:

Chicago Gay Liberation," in Out of the Closets, 346-48.

65 "Gay Man in Philadelphia," Come Out! 1, no. 7 (December-January 1970): 1516.

66 "Gay Protest Rally-Dance,” Bell Papers, Box 94, Weinstein Hall Folder. See also Arthur Bell, "Ray Rivera is Known as Sylvia to his Friends," September 1970, Bell Papers, Box 93, Gay Power Scripts Folder.

67 Arthur Bell, “Sylvia Goes to College: 'Gay is Proud' at NYU,' Village Voice, 15 October 1970, 61. See also Rivera, interview by Duberman, 14 October 1990, Audiotape 02890, Duberman Papers.

68 Arthur Bell, "Sylvia Rivera is Known as," Bell Papers, Box 94, Weinstein Hall Folder.

69 Ellen Broidy, "Gay Action N.Y.U.” Come Out! 1, no. 7 (1970): 4.

70 Bell, "Sylvia Rivera is Known as," Bell Papers, Box 94, Weinstein Hall Folder. According to the administration, student residents did not have the authority to rent out facilities to outside groups. Tellingly, GAA was absent from NYU.

When Marty Robinson of GAA heard about the eviction, he suggested that the whole sit-in had been planned by the "radical elements" of GLF as a plot to confront police. See Arthur Bell, Dancing the Gay Lib Blues: A Year in the Homosexual Liberation Movement (New York: Simon and Schuster, 1971), 118-19.

71 Cohen, The Gay Liberation Youth Movement in New York, 112.

72 Bell, "Sylvia Rivera is Known as," Bell Papers, Box 94, Weinstein Hall Folder.

73 Rivera's STGP was not the first trans youth group to articulate a notion of "street power." According to Susan Stryker, Vanguard, an organization formed in 
San Francisco's Tenderloin neighborhood in the summer of 1966, composed mostly of young gay hustlers and "transgender" people, was the earliest known US queer youth group. Vanguard sought to embody and represent "kids on the street." Much like Rivera's STAR, it promoted “street power" alongside mutual support and an assertion of community presence. See Stryker, Transgender History, 72.

74 Sylvia Rivera, Street Transvestites for Gay Power statement, NYPL, Manuscripts and Archives, IGIC, Organizations: STAR. Credit: International Gay Information Center Collection. Manuscripts and Archives Division. The New York Public Library. Astor, Lenox, and Tilden Foundations.

75 Stein, City of Sisterly and Brotherly Loves, 333.

76 As Laclau and Mouffe have suggested, the autonomous nature of groups like STAR is generated within pluralist contexts - Stonewall, the RPCC, and Weinstein. See Arthur Bell, "STAR Trek: Transvestites in the Street," Village Voice, 15 July 1971, 1, 46.

77 Rivera, "Queens in Exile," 81. In a later interview, Marsha P. Johnson modestly stated that STAR was entirely Rivera's creation. Johnson merely followed "behind" Rivera, loyally, as her Vice President. See "Pay It No Mind: The Life and Times of Marsha P. Johnson," YouTube video, 55:31, from Pay It No Mind: The Life and Times of Marsha P. Johnson, dir. by Michael Kasino and Richard Morrison (2012), posted by ReduxPictures, 15 October 2012, http://www.youtube.com/watch?v=rjN9W2KstqE.

78 Eric Marcus, Making Gay History: The Half-Century Fight for Lesbian and Gay Equal Rights (New York: HarperCollins, 2002), 152.

${ }^{79}$ Stryker, Transgender History, 86.

80 Cohen, The Gay Liberation Youth Movement in New York, 40.

81 Rivera, "Queens in Exile," 81. See also Rivera, "I'm Glad I was in the Stonewall Riot," 107.

82 Cohen, The Gay Liberation Youth Movement in New York, 2.

83 Rivera, "I'm Glad I was in the Stonewall Riot," 107.

84 Cohen, The Gay Liberation Youth Movement in New York, 2, 92.

85 Bronski, "Sylvia Rivera."

86 Young, "Rapping with a Street Transvestite," 113.

87 "Street Transvestite Action Revolutionaries," NYPL, Manuscripts and Archives, Morty Manford Papers, Box 38, STAR. Credit: Morty Manford Papers. Manuscripts and Archives Division. The New York Public Library. Astor, Lenox, and Tilden Foundations.

88 Bell, "STAR Trek."

89 Bell, Dancing the Gay Lib Blues, 145-46. At the same meeting in which GAA denied Rivera stereo equipment, it allocated 35 dollars to be spent on Christmas 
cards.

90 Rivera, interview by Duberman, 12 October 1990, Audiotape 02888,

Duberman Papers.

91 Bell, "STAR Trek."

92 See Huey P. Newton and Bobby Seale, "What We Want / What We Believe," in The Black Panthers Speak, ed. by Philip S. Foner (Cambridge: Da Capo Press, 1970), 2-6.

93 Rivera, interview by Duberman, 12 October 1990, Audiotape 02888, Duberman Papers.

94 Arthur Bell and Sylvia Rivera, "Chris: Gay Prisoner in Bellevue," Gay Flames, 14 November 1970, 1, 2, 7.

95 Cohen, The Gay Liberation Youth Movement in New York, 130.

96 Ibid., 136.

97 Katsiaficas, “Organization and Movement," 30. Donn Teal suggests that the Convention organizers had agreed to pay the University for the rental of three campus buildings over the three-day weekend but that only a portion had to be pre-paid. When University officials later demanded full payment in advance, the organizers refused to acquiesce. See Teal, The Gay Militants, 218.

98 Rivera, interview by Duberman, 14 October 1990, Audiotape 02890, Duberman Papers.

99 “Tribes Come Together in the Nation's Capital," City Newspaper [?], Bell Papers, Box 90, Gay Community Center Folder.

100 Rivera, interview by Duberman, 14 October 1990, Audiotape 02890, Duberman Papers. Rivera hustled to pay back the money she had embezzled from STAR.

101 "Tribes Come Together in the Nation's Capital," City Newspaper [?], Bell Papers, Box 90, Gay Community Center Folder.

102 The fourth demand of the Panthers' Ten-Point Program reads: "We want decent housing, fit for shelter of human beings." See Newton and Seale, "What We Want / What We Believe," 2; "Third World Gay Revolution," Come Out! 1, no. 7 (December-January 1970): 16-17; Katsiaficas, "Organization and Movement," 26-27.

103 Katsiaficas, "Organization and Movement," 30-31.

104 Susan Stryker has noted how the US's dwindling involvement in Vietnam by 1973 propelled a cultural shift away from expressions of hippie gender transgression by non-trans men to a unified, masculine "clone look" in gay male culture that signaled a return to more gender-normative iterations of male homosexuality and a concomitant further distinguishing of gay from trans communities. This distinction was also fueled by the removal of homosexuality from the American Psychiatric Association's Diagnostic and Statistical Manual of Mental Disorders, 
which differentiated the two communities with regard to how they would address their treatment by the mental health establishment. See Stryker, Transgender History, 95-98.

105 Bell, "STAR Trek." See also Bronski, "Sylvia Rivera." The GAA did not think the bill would pass while representing such "extreme" constituencies, a doubt perhaps validated by the fact that the bill, even in its restricted form, did not pass until 1986.

106 Rivera, Talk at LGMNY, 121. See also Rivera, interview by Duberman, 14 October 1990, Audiotape 02890, Duberman Papers.

107 Rivera, interview by Duberman, 14 October 1990, Audiotape 02890, Duberman Papers. Echoing Rivera's rage that day in 1973 was Lee Brewster, well known to the cross-dressing community, who threw her tiara into the crowd after witnessing Rivera's altercation and said, "Fuck gay liberation." See Rivera, Talk at LGMNY, 121.

108 Cohen, The Gay Liberation Youth Movement in New York, 158.

109 George Katsiafiacas, e-mail to the author, 26 April 2012; All Power to the People!: The Black Panther Party and Beyond, dir. by Lee Lew-Lee (New York: Filmmakers Library, 1996); videocassette; LeBlanc-Ernest, “"The Most Qualified Person to Handle the Job," 315.

110 Grady-Willis, "The Black Panther Party: State Repression and Political Prisoners," 374-75. See also LeBlanc-Ernest, “"The Most Qualified Person to Handle the Job,"' 316.

111 Stein, City of Sisterly and Brotherly Loves, 337.

112 Ibid., 339.

113 For more on the presumed homogeneity of the "functionalist" service state see Gianfranco Poggi, “The Modern State and the Idea of Progress," in Progress and its Discontents, ed. by Gabriel A. Almond, Marvin Chodorow, and Roy Harvey Pearce (Berkeley: UC Press, 1982), 359.

114 Ann Laura Stoler and Frederick Cooper, "Between Metropole and Colony: Rethinking a Research Agenda," in Tensions of Empire: Colonial Cultures in a Bourgeois World, ed. by Stoler and Cooper (Berkeley: UC Press, 1997), 35.

115 See Wendy Brown, Walled States, Waning Sovereignty (New York: Zone Books, 2010), 53. Brown has critiqued "melancholic" leftist movements for dwelling within the "wounded attachments" of their own subjugation without altering the sociopolitical spaces of domination that sustain it. See Wendy Brown, States of Injury: Power and Freedom in Late Modernity (Princeton: Princeton University Press, 1995), 7.

116 Cohen, The Gay Liberation Youth Movement in New York, 161.

117 Liz Highleyman, “Transgender Pioneer Sylvia Rivera Dies,” Bay Area Reporter, 28 February 2002. Chelsea Goodwin, who co-founded Transy House, had been 
one of Rivera's original STAR "kids." See Rivera, "Queens in Exile," 84.

118 Rivera, Talk at LGMNY, 122. See also Z. A. Martohardjono, "Changing House Clip," YouTube video, 1:59, posted by "Frameline," 20 January 2010, http://www.youtube.com/watch?v=6JQn0kFyoTs.

119 Rivera, "Queens in Exile," 84.

120 "Sylvia Rivera Trans Movement Founder," YouTube video, 25:09, from Tara

Mateik and Denise Gaberman, Sylvia Rivera Tribute Tape, Paper Tiger TV, 2002, posted by "RandolfeWicker," 27 July 2011,

http:/ / www.youtube.com/watch?v=ybnH0HB0lqc\&feature=results_main\&playn ext $=1 \&$ list $=$ PLF32A3E0BD4A373FF.

121 See Empire State Pride Agenda, "Lawmakers Introduce Bill Banning Transgender Discrimination Across New York State," Press Release (14 April 2003); available online: http://www.prideagenda.org/Press-and-

Publications/Press-Releases/Press-Release/c/298.aspx; "Assembly Approves

Gender Expression Non-Discrimination Act," The Post-Star News, 1 May 2012; available online: http://www.poststarnews.com/news/x1942568890/AssemblyApproves-Gender-Expression-Non-Discrimination-Act?zc_p=1; Liz Highleyman, "Sylvia Rivera: A Woman Before Her Time," in Smash the Church, Smash the State!, 175. 